\title{
ISLAM IN POST-SOVIET KAZAKHSTAN: EXPERIENCING THE PUBLIC REVIVAL OF ISLAM THROUGH INSTITUTIONALISATION
}

\author{
Bilal Ahmad Malik* \\ "We are proud to be a part of the Muslim Ummah. It is part of our traditions. \\ However we should not forget that we also have secular traditions, \\ and that Kazakhstan is a secular state." \\ - N.A.Nazarbayev \\ The First President of Republic of Kazakhstan
}

\begin{abstract}
After independence, Kazakhstan experienced widespread sociopolitical transformation reflecting the state's conscious policy of integrating the "continuity" of the Soviet legacy with a "return" to pre-Soviet sacred-cultural history. One such notable transformation was the end of the Soviet oppression of religion and emergence of the phenomenon of Islamic revival. In the years following independence, discussions around Islamic revival as a potential threat to Kazakhstan's security and secular objectives, including the relationship between state, society and religion, overtook the academic, political, and policy discourse. Nevertheless, the question essential to contextualising the whole debate is whether Islamic revival follows the same normative conditions as predicted by the privatisation of religion theory, reducing religion to an individual's "private matter," or has it become a dynamic social function that affects people's lives both at a personal and public level? To methodologically approach this question, this study discusses theoretical formulations relevant to the revival of Islam in a post-Soviet Kazakh context. Then the study examines the practical impact of Islamic revival, referencing the institutionalisation of Islam through religious, economic and political institutions. The study argues that since independence, despite the secular and authoritarian nature of the government, Islamic revivalism has become an institutionalised phenomenon in Kazakhstan, its appearance and function in the public domain increasing rather than decreasing.
\end{abstract}

Keywords: Islamic Revival, Kazakhstan, Institutionalisation of Islam, PostSoviet Central Asia. 


\section{Introduction}

The prediction that "the sacred shall eventually disappear altogether except, possibly, in the private realm" has proven to be misguided, especially in the Muslim world. The classical secularisation doctrine espoused by seminal social thinkers as diverse as Voltaire, Jefferson, Marx, Comte, Muller, Mills, Spencer, Durkheim, Weber and Freud is currently experiencing the unremitting challenge of history. ${ }^{2}$ Some thinkers have even suggested placing the secularisation doctrine on the list of dead theories. ${ }^{3}$ After considering contemporary theories on the sociology of religion, it is very explicit that the secularisation theory comes into question because of, firstly, its incapacity to produce relevant propositions for remarkable religious changes in the modern world and, secondly, the absence of the theory's particularity. As highlighted by scholars like Hadden, this renders the secularisation project a "hotchpotch of loosely employed ideas rather than a systematic theory." 4

According to Casanova, the two principal concepts of the secularisation theory, the decline of religious beliefs and practices and the privatisation of religion, actually face much criticism because of their asymmetrical development. ${ }^{5}$ In their recent research, Achterberg et al further elaborated on the idea of the asymmetrical development of sub-themes of the traditional secularisation theory, remonstrating that the decline of religion (for their research, Christianity) with the advance of modernism reciprocally promoted the potential for its "public revival" rather than expected "privatisation". ${ }^{6}$ In case of the Muslim world up to the 1970s, largely because of colonisation and rapid secular political developments in countries such as Turkey, Iran, Egypt, Algeria and Syria, secularisation trends, in tandem with modernisation, overwhelmingly dominated the collective or public expression. ${ }^{7}$ However, in the last quarter of twentieth century things changed drastically as a result of de-colonisation ideas and liberation movements. The Islamic world witnessed a paradigm shift, from secularisation to a "return to the sacred" as a solution to socio-political problems. The historical narratives and socio-political transformations at the local and global levels set the conditions for an Islamic revival. This movement has been reflected in increased participation in various forms of worship (ibadah), such as salah (prayer), sawm (fasting), and zakah (obligatory charity). The number of Muslims observing "normative values" (describing halal and haram) and subscribing to Muslim identity publically increased. Simultaneously, Islam reemerged in collective or public life. Throughout the Muslim world, engagement with religion took an organised form, exemplified through the excessive use of Islamic symbols, slogans, ideology and the formation of Islamic socio-political movements, Islamic educational centres and Islamic financial institutions. ${ }^{8}$ 
By the end of the twentieth century, "Islamic revivalism" had developed into a global phenomenon, shaping the Muslim ideological landscape and postcolonial worldview. The newly liberated Central Asian region was no exception. After the fall of the Soviet communist regime in 1991, the five Central Asian republics (Kazakhstan, Kyrgyzstan, Turkmenistan, Tajikistan and Uzbekistan) underwent widespread socio-political transformations, affecting people's lives individually and collectively. Scholars characterised this transformation as a conscious integration of "continuity" (of the Soviet legacy) and "return" (to the pre-Soviet historical-cultural legacy). One notable transformation was the replacement of the Soviet oppression of religion (de facto imposed atheism) with a post-Soviet moderate secularisation that allowed people to profess and practice their respective religions. All five republics therefore witnessed the emergence of an Islamic revival, both at the private and public level. However, differences manifested themselves with regards to the extent to which each republic allowed its post-Soviet socio-political space to adjust and adopt the diverse contents of the Islamic revival process.

\section{Revival of Islam in the Kazakhstan: Theory and Practice}

Today, religion (including Islam) has apparently lost its social function in the West. But, in non-Western societies, the situation is quite different. For example, in regions such as South Asia, the Middle East and North Africa, religion continues to play a vital role in the socio-political setting. ${ }^{9}$ It guides people's lives, both in private and public matters. In countries such as Pakistan, Malaysia, Indonesia, Iran, Egypt, Qatar, Saudi Arabia, Tunisia, and Algeria the religion of Islam remains instrumental in shaping the political behaviour and regime preferences of the masses. Both ruling governments and opposition parties use Islam to reinforce their legitimacy and mobilise popular support. However, in the Central Asian region, the religious situation is relatively more complex. From the religious demographic point of view, Islam is the majority religion of the region but, unlike in other Muslim countries, Central Asian Muslims do not practice Islam in a strict scriptural sense. Most Central Asian Muslims, including Kazakhs, have abandoned their religious duties after seventy years of communism. Nonetheless, after independence there has been a gradual revival of Islamic values, traditions, institutions and identity throughout the region. ${ }^{10}$ Islam emerged as a potential "cultural authority" to fill the vacuum created by the fall of Soviet communism that had controlled the region's "public expression".

When engaging with the sociology of religion in Central Asia, the Soviet "hostile to religion" model of secularisation needs due consideration in order 
to develop an effective analysis of post-Soviet propositions. This hostile policy of the Soviets serves to critique the predominant narrative that secularisation in tandem with modernisation was the reason for Central Asian Muslims abandoning religion. Instead, Soviet state oppression of religion was actually the major reason. Nonetheless, it would be a gross mistake to create the impression that regime change was the only factor responsible for Islamic revival in Central Asia. Together with an influx of myriad Islamic influences from Turkey, the North Caucasus, the Gulf and South Asia, in addition to the revival of local Islamic representations (which were dormant under the Soviets), ${ }^{11}$ there are other factors to consider, such as crises of modernity, corruption, lack of political space, relative deprivation, and educational backwardness. ${ }^{12}$ Totally relying on the discourse of "regime change" would bring simplistic and inappropriate conclusions.

To analyse these factors and their impact on the socio-psychological attitudes of Muslims vis-à-vis 'Islamic revival,' scholars have applied various theoretical formulations such as collective behaviour theory, resource mobilisation theory, political process theory and cultural and identity framing theory. Although these theories were developed to understand Christianity in the West, I will also apply them when engaging with different aspects of Islamic revival in Kazakhstan, the largest republic of Central Asia.

Just as the Kazakh version of Islam (the Hanafi juristic tradition mixed with the pre-Islamic cultural practices of shamanism and Tengrism) is different from mainstream Islam, the nature of Islamic revival in Kazakhstan is also different. In Kazakhstan, we do not find personalities like Mawlana Iliyas (founder of Tabligi Jama'at), Syed Mawdudi (founder of Jam'ati Islami), and Hassan al-Banna (founder of Ikhwan al-Muslimun), who criticised the decay of Muslim thought and Western cultural aggression, while simultaneously calling for the revival of Islam as a source of ideology and system of living. Also, we do not find any local ideological religious movements that can mobilise the people for the cause of Islam. For the majority of Kazakh Muslims, the revival of Islam does not mean accepting shariah (Islamic law) as a complete code of life, but rather a "return to religion" in terms of certain beliefs, practices and normative values. ${ }^{13}$

Although the fundamental objective of this research paper is to study the public revitalisation of Islam in Kazakhstan on the basis of institutionalisation, I also refer to three sociological theories - cultural and identity theory, collective behaviour theory and resource mobilisation theory — in order to understand some socio-cultural aspects of Islamic revivalism in Kazakhstan within a broader theoretical framework.

I start my theoretical discussion with cultural and identity theory, which elaborates on shared cultural identity. Culture is learned and transmitted through different generations until it becomes a source of shared identity. In a culture, 
individuals develop a unique "belongingness" through shared traditions, values, and religious beliefs. This sense of belongingness communicates and preserves the particularities of a group despite any changes. This shared cultural identity has the potential to mobilise people and become a trigger for collective action in the event that a culture is suppressed and forced to dissolve its particularities so that its distinctive character is lost. ${ }^{14}$ After independence, Kazakhstan searched for its cultural heritage, which historically came in the form of Islam and "Muslimness." This "Muslimness," which was suppressed under Russification and then under Sovietisation, was recognised as a "sacred legacy" that has a legitimate role in shaping the post-Soviet identity.

Collective behaviour theory propounds that societies normally enjoy a state of equilibrium and any sort of disturbance produces psychological consequences, which in turn stimulate collective behaviour. ${ }^{15}$ The argument is that, when problems are profound, society responds and produces "collective action." If there is breakdown in the entire social system, the level of anxiety deepens, pushing individuals to search for an alternative system to stabilise and channelise collective behaviour. Scholars who engage with the phenomenon of Islamic revival in Central Asia, including Kazakhstan, produce a common observation that the breakdown of the Soviet social system based on communism created an ideological and authority vacuum in the whole region. This vacuum mobilised collective behaviour and pushed locals to search for an alternative, which appeared in the form of Islam.

Lastly, I refer to resource mobilisation theory, which argues that resources are vital in the formation and endurance of collective action. The mobilisation of an organisation or of a group largely depends on the extent to which they can control and make effective use of all types of resources, such as material resources, legitimacy resources, and institutional resources. ${ }^{17}$ Here, I add one more type: 'ideological resources.' I propose that the strength of an organisation also depends on the communicative strength of its ideology. Independent Kazakhstan witnessed rapid construction of Islamic institutions (for example, masjids), the networking of Muslim communities, and the production of Islamic literature. Members of both 'official' and 'unofficial' Islam started communicating their ideas, recruiting members and building religious networks. The muftiate (Religious Board), representing 'official Islam', established local units in all Kazakh cities and, similarly, Islamic groups such as Piety Movement, Gülen Movement, and Hizb ut-Tahrir Islami, representing 'unofficial Islam,' engaged with local Muslim populations to strengthen their networks. ${ }^{18}$

After this brief theoretical analysis, I want to discuss what Islamic revival has gained on the practical side. In Kazakhstan, the beginning of Islamic revivalism was more akin to privatisation. But, in the more recent years of independence, it 
has taken the form of public or collective revitalisation through the establishment of new religious institutions, network building, a growing presence in civil society dynamics, and constitutional provisions. The first change that the Nazarbayev government implemented was the establishment of a separate muftiate to guide the Muslims of Kazakhstan. Also, after independence, the Nazarbayev government time and again endorsed the vitality of the Islamic faith vis-à-vis the preservation of Kazakh history and the nation's sacred cultural heritage. In one of his early writings, namely Critical Decade, Nazarbayev wrote:

For us, the Kazakhs, Islam is, first and foremost, a high ideal and factor that determines our worldview, a kind of symbol, allowing to pay tribute to our ancestors and the rich Muslim culture, which once were threatened by complete oblivion. ${ }^{19}$

Recent research suggests that Islam's social assertiveness and public appearance in Kazakhstan has increased rather than decreased. The phenomenon of Islamic revival is gradually expanding, from 'individual' to 'collective', from masjid to market, from mehrab (pulpit) to media, and from spiritual ethos to national identity. Based on studies conducted in different parts of Kazakhstan, there is empirical evidence supporting the proposition that individual religiosity is increasingly, which generally includes subscribing to certain religious beliefs, such as belief in one God (tawhid), ${ }^{20}$ belief in Prophethood (risalah), belief in the hereafter (akhirah), and observing certain religious practices, such as salah (namaz in Kazakh), sawm (oraza in Kazakh), and eating halal food (permissible in Islam). ${ }^{21}$ The number of masjids (Muslim places of worship) has also increased to 2,516 as of 2016, up from 68 in 1991. This is the equivalent of a 37-fold increase in the span of 25 years. ${ }^{22}$ The regular attendance of namazkhans (in Kazakh, those who attend daily prayers) varies from 50 people (in small masjids) to 300 people (in bigger masjids, like Hazrat Sultan Masjid in Astana and the Central Masjid in Almaty). Nevertheless, on Fridays all masjids are filled to capacity. Mostly young and middle-aged people attend the prayers. ${ }^{23}$

According to a 2012 Pew report, ${ }^{24} 30$ percent of Kazakh Muslims fast during the month of Ramadhan and the number of hajj pilgrims has increased from 228 in $2001^{25}$ to 3,000 in $2018,{ }^{26}$ which is remarkably higher than during the Soviet period. Women dressed morally (wearing headscarves) have become more visible in marketplaces and city streets, ${ }^{27}$ especially in the country's southern and western cities, such as Turkestan, Shymkent, Taraz and Aktobe. ${ }^{28}$ Islamic traditions are observed at the birth of new born babies, during wedding ceremonies and in funeral rituals. Similarly, the halal market industry, which includes halal food products, halal restaurants and halal fashion shops, has experienced swift growth 
over the past decade. Marlene Laruelle, a prominent Central Asian expert, has referred to it as the revival of a so-called "bourgeois" Islam, i.e. an Islam practiced and exhibited by the urban middle classes. ${ }^{29}$ Today, Kazakhstan has 130 halal slaughterhouses and over 600 halal businesses, which is a very large increase against the eight halal special units of 2002. Halal products (with halal brand logos) are visible in bazaars and shopping malls to attract Muslim customers who prefer to maintain halal standardisation. ${ }^{30}$

The above supports the argument, put forward by Azade-Ayse Rorlich in his paper published in Nationalities in 2003, that post-Soviet Kazakhstan is unfolding the process of "re-Islamisation." ${ }^{31}$ Now the question at hand is, does this so-called "re-Islamisation" happen at the public level also, or is it just a private matter restricted to an individual's personal choice?

\section{The Institutionalisation of Islam in Kazakhstan}

The process of institutionalisation is a crucial stage in the life of a religion. I propose that the institutionalisation of religion is a dual process. First, the process pertains to the development and propagation of ideas, beliefs and practices which are exclusively religious in nature and manifestation (for example, salah and sawm). Second, the process also pertains to religion vis-à-vis controlling the mechanism and functioning of social institutions that are apparently non-religious. For example, banking is apparently non-religious but, for the last two or three decades, there has been an organised movement to institutionalise Islam through so-called 'Islamic banking,' in which Islamic teachings pertaining to business transactions and monetary dealings are adopted. ${ }^{32}$ Here it is worth mentioning that those sociological theories on religion which differentiate between religious and non-religious institutions, as in Christianity, are not appropriate to the Islamic tradition; while Islam does accept classification in a restricted sense, it does not accept division. In consequence, when I say "religious" and "nonreligious", I do not use these terms in the typical sociological sense (actually fitting to Christianity). Instead, I use them in the sense of a classification that has been approved and used by religious scholars.

The institutionalisation of Islam in Kazakhstan can be viewed as having the socio-political dimension of the post-Soviet inclusive integration process. The salient role of Islam in the consolidation and integration process can be explained by examining the historical and cultural trajectory of Islam in Kazakhstan. That trajectory has shaped the behaviour and identity of the Kazakh people for over twelve centuries, producing a rich civilisational legacy. The new epoch of independent Kazakhstan demanded the restoration of that historical civilisational 
legacy; although Nazarbayev adopted a secular constitution and declined to have a state religion, he recognised the strong historical ties between Islam and the socio-cultural life of Kazakhstan. He knew the importance of the spiritual culture of Islam in the consolidation of Kazakh nationhood, ${ }^{33}$ even saying: "Islam is not only a religion, but also one of the factors that shapes our culture and our origins. ${ }^{.34}$ In the following section, I systematically analyse how Islamic revival became an institutionalised process.

\section{The Institutionalisation of Islam through Religious Institutions: The Role of SAMK}

On 12 January 1990, in agreement with the first Congress of Muslim Scholars of Kazakhstan (kurultai in Kazakh), Nazarbayev established the Spiritual Administration of Muslims of Kazakhstan (Qazaqstan Musylmandary Dini Basqarmasy, SAMK hereafter) to maintain the official relation between state and Islam. The purpose of the muftiate (another name for SAMK) was to orchestrate post-Soviet Muslim consciousness and religious worldview. It would provide guidance and issue fatawa (legal rulings) related to religious matters, family issues, social problems, community relations, and state-society relations. For example, while responding to the discourse of political Islam, SAMK unconditionally nullified the possibility of establishing an Islamic state, repeatedly advocating a more moderate interpretation of Islam accommodative of the country's multi-ethic character and secular objectives. ${ }^{35}$ The principal areas of SAMK's activities are: i) to disseminate Islamic knowledge in post-Soviet Kazakhstan; (ii) to produce religious specialists capable of making a progressive synthesis between scriptural knowledge, Kazakh $u r f$ (custom) and the secular objectives of the country ${ }^{36}$ (iii) to arrange production, publication and distribution of Islamic literature; (iv) to promote multi-faith and multi-ethnic relations within an Islamic sense of coexistence; and (v) to contribute to nation-building and the preservation of the cultural heritage of Kazakhstan. ${ }^{37}$

Since SAMK officially controls the propagation of Islam, it has direct control over entire networks of masjids and madrasas (schools of formal religious education). The network of masjids in Kazakhstan is the country's largest religious institution and communicates Islamic knowledge to the masses while addressing religious problems. It is a grassroots level institution that connects Kazakh people of all social stratifications and ethnic origins, providing them with a uniform spiritual platform. ${ }^{38}$ For example, besides daily prayers, during Friday prayers (jum'ah salah) thousands of people attend the special khutbah (religious sermon) delivered by the imam. ${ }^{39}$ The contents of the lecture, prepared 
by SAMK, focuses on the spiritual and moral values of Islam, the Islamic history of Kazakhstan, and the role of Islam in the consolidation and stability of the country. ${ }^{40}$

The network of madrasas is the second largest institutional structure of Islam in Kazakhstan. The number of madrasas registered with SAMK is 12, with a total enrolment of 17,017 students. ${ }^{41}$ The fundamental purpose behind establishment of the madrasa schooling system was to produce a network of young students well-versed in Islamic knowledge, who would be able to: (i) communicate the discourse of a synthesis between religious and secular values to the youth-the generation who represent the aspirations of a modern, secular and democratic Kazakhstan; (ii) contextualise the interpretation and application of Islamic teachings within the rapidly changing socio-political dynamics of Kazakhstan; and (iii) promote Kazakhstan's 'official' Islam as an effective cultural antidote to religious intolerance, violence, radicalisation and terrorism. ${ }^{42}$

Here, I must also mention two other prominent institutions of Islamic learning registered with SAMK: the Nur-Mubarakh Egyptian University of Islamic Culture and the Islamic Institute of Training Imams, both in Almaty. The NurMubarakh University was founded in 2003 and serves as the highest institution of formal Islamic education in Kazakhstan. The university has academic affiliations with Egypt's al-Azhar University (the oldest university in the Muslim world, representing Sunni Islam) and offers diplomas, Masters degrees and Ph.D. courses in the discipline of Islamic Studies. ${ }^{43}$ The university has an attached masjid symbolising the historical correlation between theory and practice in the Islamic tradition. The Islamic Institute of Training Imams was established in 2002, when the Islamic Development Bank (IDB), Jeddah, together with SAMK and the Ministry of Justice of Kazakhstan, signed an agreement. The main objective of the institute is to train imams by increasing their level of Islamic knowledge and improving their Arabic language proficiency. From 2002 to 2017, more than 1,000 imams from across Kazakhstan successfully completed their internships at the institute. ${ }^{44}$

Another important role of SAMK is to engage with the media. In 2015, SAMK signed an agreement with Asyl Arna, the most popular Islamic television channel and media company in Kazakhstan. The programmes broadcast on Asyl Arna are mostly related to guiding the spiritual and social life of Kazakh Muslims. It again represents the 'official' Islam of Kazakhstan that supports inter-ethnic and inter-religious peace in order to strengthen the stability and unity of the country. Asyl Arna broadcasts programmes such as Bas Mufti Bagany (The Word of the Mufti), Friday Uagyzy (Friday Guidance), and Iman Shuagy (Beam of Faith). ${ }^{45}$ According to Wendell Schwab, Asyl Arna maintains nearly identical social media pages on vKontakte (with over 155,000 followers), Facebook (with over 18,000 
likes), and on Twitter (with over 9,000 followers). ${ }^{46}$ Through these media outlets, SAMK outlines Islamic obligations using simplified instructions. ${ }^{47}$ For example, it presents the namaz (basic obligation) of prayer using the simplest possible image of four movements. This pictorial representation of namaz helps viewers memorise the four movements easily, without getting into detailed juristic discussions (see image 1).

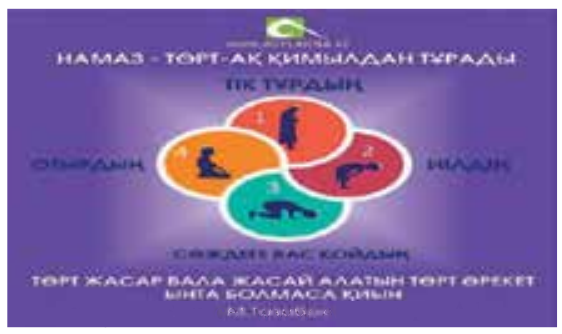

Similarly, SAMK highlights important social goals that are central to Muslim communities. For example, it has put out graphics reminding followers that "peace is more precious than money" (image 2) and "Marriage is the path out of poverty" (image 3 ).
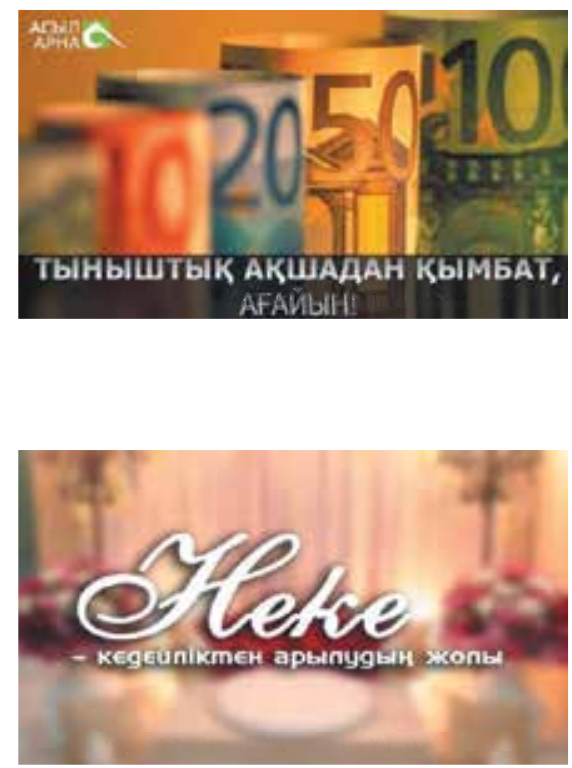

SAMK also publishes original and translated Islamic texts, varying in content 
from 'ibadat (acts of worship) to mu 'amalat (social dealings). This literature is available both online and in print. All online literature is available for free download. SAMK also publishes its monthly mouthpiece, iman (faith), which covers different aspects of Muslim life, both generally and in Kazakhstan specifically. ${ }^{48}$

\section{The Institutionalisation of Islam through Non-Religious Institutions}

In this section, I systematically examine the interplay between the public revitalisation of Islam in Kazakhstan and two prominent non-religious institutions, namely banking and politics. These two institutions play a constructive role in shaping the contemporary socio-political landscape of Kazakhstan. It is worth mentioning that the institutionalisation of Islam in Kazakhstan through both banking and political institutions depends upon the latter two's capacity for allowing Islamic teachings to regulate their operational mechanisms within a secular environment. The evidence suggests that the inclusionist policies of the government seem to encourage the public revitalisation of Islam within an emerging Kazakh civil society.

\section{(Islamic) Financial Institutions}

The experts have predicted that emerging markets will drive growth in Islamic financial institutions over the next decade. Kazakhstan, which according to a Thomson Reuters report is "on the radar of the industry," is one of these emerging markets. This report also suggests that Kazakhstan has the potential, not only to establish a successful domestic Islamic finance market, but also to become a regional hub in this area. The development of Islamic financial institutions in Kazakhstan dates back to the end of the 1990s, when a Saudi billionaire businessman, Sheikh Saleh Kamel, founder of the Dallah al-Baraka Group, invested in shariah-compliant projects in the country. ${ }^{49}$ Subsequently, in 1996, the Islamic Development Bank (IDB) opened a representative office in Almaty, then the capital of Kazakhstan. From 1997 to 2013, IDB spent US\$1.3 billion in Kazakhstan, putting the republic ahead of its Central Asian neighbours in terms of funds received. ${ }^{50}$ The country became the first IDB member country in the CIS region to join the Islamic Corporation for the Insurance of Investment and Export Credit (ICIEC) in 2002. ${ }^{51}$ In 2003, Kazakhstan's largest bank, Bank Turan Alem (BTA), became the first Central Asian financial institution to draw on a shariah-compliant line of credit when it borrowed US\$250 million from 
Arab, British and Malaysian lenders. In the spring of 2007, BTA signed a memorandum of understanding with Dubai-based Emirates Islamic Bank for the promotion of shariah-compliant banking operations in Kazakhstan and other CIS states where BTA has subsidiaries. Later, in 2007, another development took place with the appearance of Fattah Finance, a consultancy and financial broker for Islamic investment and securities. The work of Fattah Finance resulted in the establishment of the Association for the Development of Islamic Finances (ADIF) in 2009. All these developments, along with growing customer demand and a "need of further foreign investments" persuaded the secular Kazakh government to pass its first law on Islamic banking in 2009 under presidential decree. $^{52}$

Currently, Kazakhstan has two Islamic banks: Abu Dhabi's al-Hilal Bank (established 2010) and Zaman Bank (2017). ${ }^{53}$ Al-Hilal offers both corporate and retail services under the supervision of the Islamic Finance Principles Board (IFPB), which issues fatawa on the bank's products and services. ${ }^{54}$ In July 2011, President Nazarbayev signed into law "the amendment on alteration and addition to some legislative acts of the Republic of Kazakhstan on the organisation of Islamic finance," paving the way for the issuance of sukuk (Islamic bonds). In November, the National Bank of Kazakhstan was admitted as an Associate Member of the Islamic Financial Services Board (IFSB), based in Kuala Lumpur, Malaysia. In the same year, the $7^{\text {th }}$ World Islamic Economic Forum (WIEF) was held in Astana. In March 2012, the government approved a road-map for the stable development of the Islamic finance industry up to 2020, promoting the establishment of new Islamic banks, Islamic securities issuers, investors, and market participants. ${ }^{55}$ In the same year, the Kazakhstan Ijarah Company (KIC) became the first Islamic leasing (ijarah) company in Kazakhstan. In 2015, the relevant laws were improved to include Islamic insurance (takaful) and, in the same year, the $12^{\text {th }}$ IFSB Summit was held in Almaty. ${ }^{56}$

Today, nearly a dozen Islamic financial institutions are successfully operating in Kazakhstan, including two Islamic Banks, an Investment Fund, a takaful company, a hajj fund, and various brokerage and consulting companies. There is still potential, however, for further substantial development in the industry, backed by political will, financial support from the IDB and initiatives from industry participants. Taking all chronological developments and future programmes into account, the Islamic finance industry in Kazakhstan can be described as "emerging" with promising prospects. Islamic finance experts believe that, if the industry focuses on growth deciding indicators such as access, availability and quality of services, professionalism, public awareness programmes and transparency, it will surely impact positively on customer behaviour vis-à-vis choice and preference. ${ }^{57}$ 
Coming to the institutionalisation of Islam through the Islamic finance industry, I propose that this is again controlled by the state itself. The amendments to the country's banking and financial laws providing the legal space for the Islamic finance industry to flourish have all been carried out under presidential supervision. Despite being secular, there is a strong will from the government to allow the development of a mechanism for Islamic financial intermediation between banks and customers. Reasons for this vary, but there appear predominantly to be four: (i) to attract capital rich investors from countries like Saudi Arabia, UAE, and Qatar; (ii) to make financial markets more competitive; (iii) to meet the demand of local market players; and (iv) to make development processes more inclusive by allowing people to participate who are behaviourally more responsive to religion and culture. The institutionalisation of Islam is integral to the philosophy of the Islamic finance industry. One of the underlying objectives of the industry is to promote an Islamic way of life through the practicing of Islamic teachings within a business setting. ${ }^{58}$ I propose that the participation of the (especially Muslim) Kazakh people in Islamic financial institutions not only indicates the level of individual religiosity in the country is increasing, but also that it becomes significant for understanding the public revitalisation of Islam in civil society. ${ }^{59}$

\section{Identity Formation and the Nation-Building Process}

The waters of identity formation and nation-building in Kazakhstan are muddy. Legally, no political party in the country can have a religious affiliation. ${ }^{60}$ The political process is monitored by authoritarian structures controlled by the president. Politically, the country therefore does not allow the instrumentalisation of Islamic ideology within active electoral politics. ${ }^{61}$ Nevertheless, it would be wrong to draw the simplistic conclusion that Islam is therefore outside the political debate. After independence, 'official Islam' became entangled in the identity formation and nation-building discourses - two momentous institutions within the political process. The political authorities recognised that a new national identity could not be constructed in a vacuum, that the reality of a deeprooted Islamic tradition could not be ignored. There is a growing body of research examining the delicate interplay between Islamic revival and the politics of identity formation and nation-building in independent Kazakhstan. ${ }^{62}$ According Omelicheva, "being Muslim is key part of Central Asian identity, including [in] Kazakhstan." As a result, Kazakh authorities accept Islam as a "source of national unity and an instrument of consolidation of the diverse ethnic groups" in the country. ${ }^{63}$ However, this official construction of identity and national ideology elaborates on the systematic manipulability of Islam and reflects the state's 
ambivalent relationship with it. While certain aspects of the identity formation and nation-building project certainly give the appearance of the nationalisation of Islam, usually in tandem with the nationalisation of a titular ethnic 'Kazakhness,' the Nazarbayev government has simultaneously counterbalanced this idea by promoting the notion of civic nationalism. ${ }^{64}$

The Nazarbayev government used religious rhetoric and employed the symbols of an 'official Islam' as part of a nationalising discourse against the Russiandominated Soviet past. This, I propose, was an implicit nationalist and not religious reaction to 'non-Kazakh' forces in the country. The first president's personal attachment to Islam is quite paradoxical; he does not tolerate political Islam but, at the same time, publically acknowledges the Islamic roots of Kazakhstan. For example, he created a separate muftiate for Kazakhstan, allowed the construction of masjids (even attending their opening ceremonies), and developed political relations with Islamic countries like Saudi Arabia and Turkey. In 1994, he also performed hajj and visited the holy cities of Makkah and Madinah. In 1995, he pressed for Kazakhstan to become a member of the Organisation of Islamic Conference (OIC). Yet, on the other hand, his government is executing a "typical Soviet and communist mindset," ${ }^{65}$ banning Muslim missionary organisations, the performance of salah inside government institutions, and hijab in educational institutions. However, quite opportunistically, as rightly pointed out by Ayşegül Aydingün, the Kazakh government has acknowledged Islam as part of Kazakh cultural heritage and national identity ${ }^{66}$ This idea worked for the state and there is a strong theoretical basis for it. To explicate it, I refer to two prominent theories: ethno-symbolism and constructivism.

Ethno-symbolism gives an accurate explanation of Islam's role in identity formation and national building in independent Kazakhstan. This theory emphasises symbols, values and traditions in the creation and perseverance of nationhood. The exponents of ethno-symbolism argue that every ethnic group historically possesses a special "collective name" differentiating it from the rest. The people associated with this "collective name" share a common history and collective memory which subsequently authorises identity formation and nationbuilding. ${ }^{67}$ This theory contextualises the Nazarbayev government's policy of applying religious symbols and religious rhetoric within the post-Soviet political discussion. For example, as mentioned above, calling Kazakhstan part of the Muslim ummah, claiming that the Kazakhs have never lost their religion, that "this (Islam) will unite us," acknowledges the fact that the Kazakh nation has its own cultural heritage and civilisational characteristics which inform the contemporary processes of identity formation and nation building.

According to the constructivism approach, in the context of political and economic change, people with common interests form groups to pursue their 
aims, with ethnicity being the most effective unifying principle. This is the de facto position of Kazakhstan after independence vis-à-vis ethnic claims. Although the Nazarbayev government proposed a doctrine of National Unity ("Kazakhstani Nation") ${ }^{68}$ in 2004, this doctrine was opposed by some prominent Kazakh cultural entrepreneurs. ${ }^{69}$ For example, prominent Kazakh politician, poet, activist, and journalist, Mukhtar Shakhanov, opposed the doctrine in the following words: Ultty zhoyudyy tote zholy - kazakhstandyk ult (the direct way to the destruction of a nation - Kazakhstani nation). ${ }^{70}$ Likewise, Kazakh ethno-nationalists also oppose this doctrine. For them, Kazakhstan is first and foremost the homeland of the Kazakhs, whose culture must be made the "first among equals." as outlined by Kadyrzhanov, those who define themselves as 'Kazakhs' and take post-colonial stances do not want to be considered as "Kazakhstanis." 72

To summarise the theoretical discussion surrounding 'Kazakhness' and its relationship to Islam within the context of national identity formation, I refer to a very prevalent statement among Kazakh intellectuals. Although the statement has different expressions, here I chose the words of Yerkin E. Ongbarbayev, Chairman of the Committee for Religious Affairs in the Ministry of Religious Affairs and Civil Society: "every ethnic Kazakh is automatically a Muslim by identity, similarly, Islam is the major marker of Kazakh ethnicity and [an] indissoluble part of national culture."73 The practical implication of this statement is that restoration of 'Kazakh identity,' as a matter of state policy, is tantamount to the manipulation of Islamic symbols. It will therefore result in the use of more political language containing Islamic content vis-à-vis identity and the nationbuilding process.

\section{Conclusion}

The Republic of Kazakhstan is a secular state, meaning Islam can never become a centralised state ideology within the country. Nevertheless, the current modus vivendi between the Kazakh state and an 'official Islam' developed by the postSoviet regime provides a new avenue of discussion concerning the correlation between the institutionalisation and public revitalisation of Islam. The Islamic revival in Kazakhstan has, in its various manifestations, from individual piety to national identity discourse, been a quite extraordinary phenomenon that rejects the 'privatisation doctrine' of classical secularisation. The government of Kazakhstan is reviving its relationship with Islam-historically, culturally and morally. The current discourse on Islamic revival and its dissemination across constitutional provisions and civil society dynamics in Kazakhstan underline the fact that Islam is reviving through various institutional structures, such as SAMK, 
Islamic banks and various political institutions. This is the public revitalisation of Islam, rather than its privatisation. In the light of the theoretical framework and practical evidences presented here, I argue that there is a limitation to Kazakhstan's claim to be a 'neutral secular establishment' because, instead of a separation with religion, the government is undertaking a 'paradoxical involvement' in religious affairs - especially with Islam. On the one hand, there are strict laws to eliminate the 'radicalisation' of Islam and contain the spread of 'un-official' Islamic influences. But, on the other hand, the government extends its support to muftiate (SAMK), adopts constitutional amendments to promote the Islamic finance industry and halal market, and uses religious rhetoric in nation-building discussions. These developments shape the current relationship between Islam and the secular state, promoting the revitalisation of Islam in the public sphere.

\section{Recommendations}

- The phenomenon of Islamic revivalism in Kazakhstan is neither a myth nor a 'political Islamist threat,' as some superficial research suggests. Rather, it has varied manifestations (as discussed here) and has moved into the collective (public) expressions of society. Therefore, there is a need to revisit the discourse from an academic point of view, to formulate appropriate propositions.

- The Islamic identity of the Kazakhs is deeply associated with their ethnic identity. Therefore, without any negative politicisation, the Kazakh state, in collaboration with SAMK, can mobilise indigenous Islamic traditions and spiritual knowledge in the quest for social consolidation, inter-ethnic and inter-religious stability, and nation building.

- The government of Kazakhstan needs to revisit its policy towards Islam, notably its decision to divide Islamic groups into 'with us' (official Islam) and 'against us' (non-official Islam) camps. This policy has aggravated the so-called 'religious problem,' further alienating the followers of 'nonofficial' Islam. This situation has pushed advocates of 'non-official' Islam (not necessarily fundamentalists or radicals) underground, instead of allowing them to enter public debates.

- The government of Kazakhstan also needs to revisit its restrictive (hostile to religion) legislation which, in its current form, is not only reprehensible but also counterproductive, since it can push followers of 'non-official' Islam towards radicalisation. 


\section{Notes}

* Bilal Ahmad Malik is a PhD researcher in the Center of Asian Studies, University of Kashmir, India. He can be contacted at gaziblal@ymail.com .

1. C. Wright Mills, The Sociological Imagination (Oxford: Oxford University Press, 1959), 32-3.

2. For a detailed discussion, see Rodney Stark, 'Secularization, R.I.P,' Sociology of Religion 60, no. 3 (1999): 249-73; Peter L. Berger, 'The Desecularization of the World: A Global Overview,' in The Desecularization of the World: Resurgent Religion and World Politics, ed. Peter L. Berger (Grand Rapids, Michigan: William B. Eerdmans, 1999), 1-18; R. Wallis and S. Bruce, 'Secularization: The Orthodox Model,' in Religion and Modernization, ed. S. Bruce (Oxford: Oxford University Press, 2001), 8-30; P. Norris and R. Inglehart, Sacred and Secular: Religion and Politics Worldwide (Cambridge: Cambridge University Press, 2004); Alan Aldridge, Religion in the Contemporary World (Cambridge: Polity Press, 2000).

3. Stark, 'Secularization, R.I.P,' 249-73.

4. For details see, Berger, 'The Desecularization of the World,'; Paul Heelas and Linda Woodhead, The Spiritual Revolution: Why Religion is Giving Way to Spirituality (Malden, MA: Blackwell, 2005); Jeffrey Hadden, 'Towards Desacralizing Secularization Theory,' Social Forces 65, no. 3 (1987): 587-610.

5. Jose Casanova, Public Religions in the Modern World (Chicago: University of Chicago Press, 1994).

6. Achterberg et al., 'A Christian Cancellation of the Secularist Truce? Waning Christian Religiosity and Waxing Religious Deprivatization in the West,' Journal for the Scientific Study of Religion 48, no. 4 (2009): 687-701.

7. Talal Assad has refuted the idea of "secular relocating the religion." For details, please see Talal Assad, Formations of the Secular: Christianity, Islam, Modernity (Stanford: Stanford University Press, 2003), 191.

8. J. Abu-Lughod, Cairo: 1001 Years of the City Victorious (Princeton, NJ: Princeton University Press, 1971); A. Bayat, Making Islam Democratic (Stanford, CA: Stanford University Press, 2007).

9. Berger, The Desecularization of the World.

10. Adeeb Khalid describes the phenomenon of Islamic revival in Central Asia in the following words: "unprecedented interest in rediscovery of the past." See Adeeb Khalid, Islam after Communism: Religion and Politics in Central Asia (Berkeley: University of California Press, 2007), 126.

11. Cornell et al., 'Religion and the Secular State in Kazakhstan,' Silk Road Working Paper (Central Asia-Caucasus Institute and Silk Road Studies Program, 2017).

12. Jean-Paul Carvalho, A Theory of the Islamic Revival (Oxford: Oxford University Press, 2009).

13. This analysis is based on my filed study data. I presented a questionnaire to 500 respondents, including students, teachers, imams (religious leaders), professionals, experts and ordinary people. To my question, "What does Islamic revival mean to them?," more than 80 percent of respondents confirmed my analysis. 
14. Alberto Melucci, Challenging Codes: Collective Action in the Information Age (Cambridge: Cambridge University Press, 1996), xiii +398.

15. Wiktorowicz, Quintan, ed., Islamic Activism: A Social Movement Approach (Bloomington and Indianapolis: Indiana University Press, 2004), 1-36.

16. For a detailed discussion, see J. Craig Jenkins, 'Socio-political Movements,' in Handbook of Political Behaviour, vol. 4, ed. S. L. Long (New York: Plenum Publishers, 1981), 81-154; Doug McAdam, Political Process and the Development of Black Insurgency (Chicago: University of Chicago Press, 1999); Aldon D. Morris and Cedric Herring, 'Theory and research in Social Movements: A Critical Review,' Annual Review in Political Science 2 (1987): 137-98.

17. Bob Edwards and John D. McKarthy, 'Resources and Social Movement Mobilization,' in The Blackwell Companion to Social Movements, ed. D. A. Snow, S. A. Soule and H. Kriesi (Oxford: Blackwell Publishing, 2004), 116-52; C. Jenkins, 'Resource Mobilization Theory and the Study of Social Movement,' Annual Review Sociology 9, no. 1 (2011): 527-54.

18. For a detailed discussion, see B. Balci, 'Fatullah Gülen's Missionary Schools in Central Asia and their Role in the Spreading of Turkism and Islam,' Religion, State \& Society 31, no. 2 (2003): 151-77; Mariya Y. Omelicheva, 'Islam in Kazakhstan: A Survey of Contemporary Trends and Sources of Securitization,' Central Asian Survey 30, no. 2 (2011): 243-56.

19. Nursultan Nazarbayev, The Critical Decade (Almaty: Zhibek Zholy Publishing House, 2010).

20. Pew Research Center, The World's Muslims: Religion, Politics and Society (Washington DC, 2013), 15. Available at: http://assets.pewresearch.org/wpcontent/uploads/sites/11/2013/04/worlds-muslims-religion politics society-fullreport.pdf.

21. Opinion polls conducted in 2014 by the Strategy Center for Social and Political Studies, Almaty, indicate that only one-tenth of all Muslims in Kazakhstan perform namaz regularly.

22. E. Nogoybayeva, Central Asia: A Space for "Silk Democracy" (Almaty: Friedrich Ebert Foundation, Almaty Club, 2017).

23. This is based on my personal observations made during fieldwork in Kazakhstan during 2017.

24. Pew Research Center, The World's Muslims: Religion, Politics and Society, 105.

25. 'Islam in Kazakhstan, National History of Kazakhstan.' Available at http://ehistory.kz/en/contents/view/485 (Accessed on: 8 August 2013).

26. '3,000 Kazakhstanis to perform Hajj', Kazinfrom. Available at https://www. inform.kz/en/3-000-kazakhstanis-to-perform-hajj_a3340817 (Accessed on: 10 August 2018).

27. Nogoybayeva, Central Asia.

28. School uniform was introduced in public schools throughout Kazakhstan in 2011 by order of the Ministry of Education and Science. However, more than 5,000 appeals have been received by the ministry as of 2016 to revoke this ban.

29. Marlene Laruelle, Kazakhstan's Nationhood: Politics and Society on the Move, A short transcript of the lecture by Dr. Marlene Laruelle Kazakhstan's Nationhood: 
Politics and Society on the Move at the Center for Eurasian, Russian and East European Studies (CERES), Georgetown University (8 February 2018).

30. Norshazlina Nor'azman, 'Growing Demand For Halal Foodstuff in Kazakhstan,' Halal Focus. Available at https://halalfocus.net/growing-demand-for-halalfoodstuff-in-kazakhstan/; Kazakhstan's \$3 billion halal food sector (Accessed on: 29 June 2017); Yerbolat Uatkhanov, 'Arab businesses urge production of halal-certified meats in Kazakhstan,' The Astana Times, Available at https:// astanatimes.com/2017/05/arab-businesses-urge-production-of-halal-certifiedmeats-in-kazakhstan/ (Accessed on: 28 December 2017).

31. Azade-Ayse Rorlich, 'Islam, Identity and Politics: Kazakhstan, 1990-2000,' Nationalities Papers 31, no. 2 (2003): 157-76.

32. Bilal Ahmad Malik, 'Islamic Banking and Finance in Emerging Countries: Study of Post-Soviet Central Asian Republics,' in Proceedings of the $26^{\text {th }}$ Annual Conference on Islamic Banking, vol. 3, ed. Mehdi Razavi (Tehran: Iran Banking Institute (IBI) and the Central Bank of The Islamic Republic Of Iran, 2015), 405-39.

33. Haji Abdsattar Derbisali, Islam: Religion of Peace and Creation (Astana: Stacey International, 2016), 218.

34. Spiritual Administration of Muslims of Kazakhstan, Islam of the Great Steppe, (np: SAMK, 2018), 57.

35. Derbisali, Islam: Religion of Peace.

36. Haji Abdsattar Derbisali, The Religious Board of Kazakhstan (np: SAMK, 2003), 115.

37. Derbisali, The Religious Board, 115-47; Omelicheva, 'Islam in Kazakhstan,' 243-56.

38. The unparalleled role of Masjid al-Nabawi (Prophet's Mosque) and Madrasa al-Sufah (the first religious educational institution established by the Prophet in Madinah) with regard to the formation of early Muslim society in Madinah suffice to confirm this argument.

39. Women also attend masjid on Fridays. They do not sit with the men in the main hall, however, but enter a special room where they listen to Qur'anic verses recited by the imam, make supplications, and give donations.

40. The imams in charge of these masjids are appointed by SAMK. Presently, there are 3,800 imams working for SAMK.

41. Spiritual Administration, Islam of the Great Steppe, 264.

42. I obtained this information from detailed interviews with the ex-Chief Mufti of Kazakhstan, Sheikh Abdsattar Haji Derbisali, and Erzhan Kazhy Malgazhauly, the present deputy Mufti of Kazakhstan.

43. Please check the official website of Nur Mubarak University, https://nmu.kz/en

44. Check this website for details, http://www.muftyat.kz/kz/kmdb/universities\&xid

45. Spiritual Administration, Islam of the Great Steppe, 227.

46. Wendel Schwab, 'Asyl Arna's Social Media, Visual Culture, and Islam in Kazakhstan,' in Nation-Branding, Economic Trials, and Cultural Changes, in Kazakhstan, ed. Marlene Laruelle (Washington, D.C: The George Washington University, Central Asia Program. 2017), 75-81.

47. Ibid.

48. For details, please check www.muftyat.kz, the official website of SAMK. 
49. 'To be or not to be? Islamic banking in Kazakhstan,' Islamic Markets. Available at http://www.almau.edu.kz/eng (Accessed on: 18 November 2017).

50. Bilal Ahmad Malik, 'Islamic Banking and Finance,' 405-9.

51. Ibid.

52. Bilal Ahmad Malik, 'Halal Banking in Post-Soviet Central Asia: Antecedents and Consequences,' Marketing and Branding Research 2, no. 1(2015): 28-43.

53. Assel Satubaldina, 'Zaman-Bank becomes Kazakhstan's second Islamic Bank,' The Astana Times. Available at http://astanatimes.com/2017/08/zaman-bankbecomes-kazakhstans-second-islamic-bank/ (Assessed on 29 November 2017).

54. Please see the official website of Al-Hilal Bank Kazakhstan, https://alhilalbank. $\mathrm{kz} /$

55. Thomson Reuters Report, Kazakhstan Islamic Finance 2016: A New Frontier for Islamic Finance (2016).

56. Bilal Ahmad Malik, 'Islamic Banking and Finance,' 405-39.

57. Thomson Reuters Report, Kazakhstan Islamic Finance 2016.

58. Munzar Kahf, 'Islamic Banks at the Threshold of the third Millennium,' Thunderbird Int. Bus. Rev. 4, no. 5 (1999): 445-60.

59. Dilshod Achilov, 'Islamic Revival and Civil Society in Kazakhstan,' in Civil Society and Politics in Central Asia, ed. C. Ziegler (University Press of Kentucky, 2015), 81-110.

60. Ibid.

61. There are two exceptions from within the state: Ak Orda (named after the house of the president) and Izgi Amal (true faith). The former was founded in 2005, by Kairat Satybaldy, nephew of President Nazarbayev and then-head of the Human Resources Department of the National Security Committee. The latter was founded in 2009 by Asylbek Mussin, ex-deputy of Atyrau city council and son of the head of the president's administration, Aslan Mussin. However, the founders could not transform their movements into political parties due to constitutional restrictions. Nargis Kassenova, 'Kazakhstan: Islamic Revival and Trajectories of State-Society Relations,' in Religion, Conflict, and Stability in the Former Soviet Union, ed. Katya Migacheva and Bryan (Frederick Santa Monica: RAND Corporation, 2018), 115-36.

62. S. Akiner, 'The Politicisation of Islam in Post-Soviet Central Asia,' Religion, State \& Society 31, no. 2 (2003): 97-122; Chris Hann and Mathijs Pelkmans, 'Realigning Religion and Power in Central Asia: Islam, Nation-State and (Post) Socialism,' Europe-Asia Studies 61, no. 9 (2009): 1517-41; Scott Spehr and Nargis Kassanova, 'Kazakhstan: Constructing Identity in a Post-Soviet Society,' Asian Ethnicity 13, no. 2 (2012): 135-51; G.M. Yemelianova, 'Islam, National Identity and Politics in Contemporary Kazakhstan,' Asian Ethnicity 15, no. 3 (2014): 286-301.

63. Omelicheva, 'Islam in Kazakhstan,' 243-56; Mariya, Y. Omelicheva, 'Islam and Power Legitimation: Instrumentalisation of Religion in Central Asian States,' Contemporary Politics 122, no. 2 (2016): 144-63.

64. Khalid, Islam after Communism, 98-103; Donnacha Beacháin and Rob Kevlihan, State-building, Identity and Nationalism in Kazakhstan: Some Preliminary Thoughts (Dublin: Dublin City University, 2011).

65. Yemelianova, 'Islam, National Identity,' 286-301. 
66. Ayşegül Aydingün, 'Islam as a Symbolic Element of National Identity Used by the Nationalist Ideology in the Nation and State Building Process in Post-soviet Kazakhstan,' Journal for the Study of Religions and Ideologies 6, no. 17 (2007): 69-83.

67. A. D. Smith, The Ethnic Origins of Nation (Oxford: Basil Blackwell, 1986); A. D. Smith, Nations and Nationalism in a Global Era (Cambridge: Cambridge University Press, 1995).

68. 'Kazakhstan's National Unity Doctrine,' Kzinform. Available at http://www. inform.kz/kaz/article/ (Accessed on: 8 November 2017).

69. Nurken Aitymbetov et al., 'Nation-Building in Kazakhstan: Kazakh and Kazakhstani Identities Controversy,' bilig no. 74 (2015): 1-20.

70. Junisbai, Junisbai and Zhussupov, 'Two Countries, Five Years: Islam in Kazakhstan and Kyrgyzstan,' Central Asian Affairs 4, no.1 (2017): 1-25

71. W. Fierman, 'Kazakh Language and its Prospects for its Role in Kazakh "Groupness",' Ab Imperio no. 2 (2005): 393-423.

72. Rustem Kadyrzhanov, 'My kazahi? Ili kazahstantsy?,' Ves mir no. 37 (2012). I am thankful to Dr. Nurlykhan Aljinova (Al-Farabi University, Kazakhstan) for helping me translate the article.

73. Mr. Yerkin E. Ongbarbayev expressed these words when I interviewed him at his office on 20 July 2017. 